\title{
Influences of Different Planting Density on Growth, Yield Attributes and Yields of hirsutum, arboreum and Bt Cotton
}

\author{
Arvind Kumar*, Anil P. Karunakar and Anil Nath \\ Dr. Panjabrao Deshmukh Krishi Vidyapeeth, Akola, Maharashtra-444104, India \\ *Corresponding author
}

\begin{tabular}{l} 
Ke y w o r d s \\
$\begin{array}{l}\text { Planting Density, Growth, } \\
\text { Yield Attributes, Yields } \\
\text { of hirsutum, arboreum } \\
\text { and Bt Cotton }\end{array}$ \\
\hline Article Info \\
$\begin{array}{l}\text { Accepted: } \\
\text { 18 May } 2018 \\
\text { Available Online: } \\
\text { 10 June } 2018\end{array}$ \\
\hline
\end{tabular}

A B S T R A C T
An optimum plant population can maximize the plant output so this field experiment was conducted to know about the Response of different planting density on various genotypes of cotton for yield maximization. In this experiment three cotton genotypes viz. hirsutum cotton (AKH-081), arboreum cotton (AKA-7) and Bt cotton (Balwan), with three plant densities level of $100 \%, 150 \%$ and $200 \%$ of normal for respective genotype, were laid out in factorial randomized block design. Bt cotton Balwan recorded higher growth in terms of leaf area, dry matter weight and yield attributes plant ${ }^{-1}$. Plant height and sympodial branches plant ${ }^{-1}$ were significantly more with AKA 7. AKA-7 recorded maximum seed cotton yield $\left(1715 \mathrm{~kg} \mathrm{ha}^{-1}\right)$ than Bt Balwan $\left(1571 \mathrm{~kg} \mathrm{ha}^{-1}\right)$ and AKH $081\left(1466 \mathrm{~kg} \mathrm{ha}^{-1}\right)$. High density planting at $200 \%$ of normal density produced maximum seed cotton yield $\left(1802 \mathrm{~kg} \mathrm{ha}^{-1}\right)$ at par with $150 \%$ of normal plant density $\left(1679 \mathrm{~kg} \mathrm{ha}^{-1}\right)$. Normal planting density recorded the maximum harvest index $(38.08 \%)$ and seed index (7.54) followed by high population densities of $150 \%$ and $200 \%$. whereas balwan observed high seed index followed by AKH-O81 and AKA-07. Highest ginning out turn recorded by AKA-07 followed by AKH-O81 and Balwan but $200 \%$ planting density reported maximum ginning out turn than $150 \%$ and $100 \%$ planting density. Increased plant population compensated for fewer yield attributes plant ${ }^{-1}$ and cumulatively yield output was higher in conventionally close spaced genotype (AKA-7) and with the high density planting system.

\section{Introduction}

Cotton is in predominant position among all cash crops in India and has retained its unique fame as 'king of fibre' and 'white gold' because of its higher economical value among all cash crops. In India, nearly 70 per cent of the crop is cultivated under rainfed conditions in the Central and Southern regions of the country and it is essential to investigate the suitable genotype which performs better under this condition. There is much scope to increase the cotton production in India by increasing the productivity through adoption of appropriate agronomic practices. The current economic climate continues to impact profit margins. With production cost on the rise due in part to increased seed cost associated with transgenic technologies, producers are searching for ways to increase efficiency. This has led to changes in seeding rates, row spacing and row-configurations such as solid 
planted, twin-rows, and skip-row patterns. With the advent of precision seed drop planters and GPS control systems, producers can manipulate plant populations to optimize yield. There is also a need to find out optimum plant density for recently released cotton hybrids to realize the maximum yield potential. Hence, the need to find out the potentiality of cotton genotypes and also to save cotton seeds with different plant densities under rainfed condition. So this study was conducted with the objective to screen out the rational plant density for yield maximization in arboreum, hirsutum and Bt cotton under the high density planting system.

\section{Materials and Methods}

\section{Experimental site}

A field investigation was carried out with the objective of the "Influence of different plant density on growth, yield attributes and yield of arboreum, hirsutum and Bt cotton" at the All India Coordinated Research Project on Agrometeorology, Dr. Panjabrao Deshmukh Krishi Vidyapeeth, Akola, Maharashtra, India during the kharif season of 2015-16. Akola is situated in the sub-tropical zone at the latitude of $22^{0} 42^{\prime}$ North longitude of $77^{0} 02^{\prime}$ East. The altitude of the place is 307.41 meter above mean sea level.

\section{Soil and climate}

The soil of experimental plot was medium deep black with fairly uniform and levelled topography with slightly alkaline in reaction with medium status of organic carbon content, available nitrogen and phosphorus and fairly rich status of available potassium. The climate of Akola is semi-arid and characterized by three distinct seasons viz., hot and dry summer from March to May, warm and rainy monsoon from June to October and mild cold winter from November to February. Most of the rain received from south-west monsoon during June to October with mean annual normal precipitation of $788.9 \mathrm{~mm}$ received in 43.7 rainy days (Average of 30 years, 1981-2010). Total rainfall of $590.8 \mathrm{~mm}$ was recorded during the crop growing season. The crop encountered two dry spell periods during first fortnight of July (23 days) and second fortnight of August (15 days). Genotype AKH 081 was found susceptible to bollworm incidence. Sap sucking pest infestations (aphids, jassids and whiteflies) and bollworm attacks were controlled by undertaking timely plant protection measures.

\section{Treatment details}

Three cotton genotypes viz. hirsutum cotton, arboreum cotton and $B t$ cotton, with three plant densities at the population level of 100 $\%, 150 \%$ and $200 \%$ of normal for respective genotype, were laid out in factorial randomized block design with three replications. The cotton crop was sown on June 18, 2015 and harvested in four pickings up to last week of December, 2015.

The important research findings are briefed below:-

\section{Result and Discussion}

\section{Growth studies}

\section{Plant Height (cm)}

Plant height increased as the crop advanced in age. The rate of increase in plant height was the maximum between branching to flowering stage. Subsequently the rate of increase was gradual down towards maturity stage.

\section{Effect of Genotype}

Plant height was significantly influenced throughout the crop growth period by different 
genotypes. At 30 day after emergence (DAE), Bt cotton Balwan recorded significantly higher plant height than AKH-081 and AKA-7 which were at par. Subsequently at 60, 90, 120, 150 DAE and at harvest stage, arboreum genotype AKA-7 attained significantly higher plant height over the remaining two genotypes. AKH-081 recorded the least plant height. Balwan recorded significantly higher plant height than AKH-081. Anwar et al., (2002), Copur (2006) and Moola and Giri (2006) noticed that the differences observed for plant height among cotton genotypes can be primarily attributed to variation in genetic makeup of plants. Moreover, different genotypes respond in different degrees to the abiotic and biotic factors.

\section{Effect of Plant density}

Differences due to plant density on plant height were found to be non-significant at 30, 60 and 90 DAE. Subsequently, from 90 DAE to harvest stage, maximum plant height was recorded in normal planting density with $100 \%$ population $\left(\mathrm{P}_{1}\right)$, which was significantly superior over high density planting at $200 \%$ of normal population $\left(\mathrm{P}_{3}\right)$ and at par with high density planting with $150 \%$ population $\left(\mathrm{P}_{2}\right)$. Treatments $\mathrm{P}_{2}$ and $\mathrm{P}_{3}$ varied non-significantly between them. These results are in conformity with Kater Hake et al., (1991) according to whom cotton seedlings tend to grow taller in thick stands. As the season progresses, plant height in thick stands tend to lag behind that of thin stands and at harvest, high density stands have the lowest average plant height. In cotton grown in ultra-narrow rows (UNR) although canopy closure was earlier, this early canopy closure did not translate into faster growth or development as high populations lead to excessive competition for photoassimilates (Rose Roche et al.,2003). Also Plant spacings directly influence soil moisture extraction, light interception, humidity and wind movement. These factors, in term, influence plant height. Singh et al., (2015) also reported that plant height attained its apogee at wider spacing. Dongsheng Zhang et al., (2014) also observed decreased cotton plant height with increased plant density above the optimum planting density.

\section{Number of sympodial branches/plant}

Data on number of sympodial (fruiting) branches plant ${ }^{-1}$ were recorded from 60 DAE to 120 DAE. Sympodial branches plant $^{-1}$ increased with increase in age of crop and attained maximum value at 120 DAE when boll bursting rate was at peak.

\section{Effect of Genotype}

The effect of genotype on sympodial branches plant $^{-1}$ was recorded significant among different genotype at $60 \mathrm{DAE}, 90 \mathrm{DAE}$ and 120 DAE. Different genotypes had significant influence on number of sympodial branches plant $^{-1}$. Genotype AKA $7 \quad\left(V_{2}\right)$ recorded maximum number of sympodial branches plant $^{-1}$ from 60 days up to 120 DAE and it was significantly superior over Balwan $\left(\mathrm{V}_{3}\right)$ and AKH $081\left(V_{1}\right)$. Balwan produced significantly more number of sympodial branches plant ${ }^{-1}$ as compared to AKH 081. The significant differences in number of sympodial branches plant $^{-1}$ among varieties of different genotypes was also have been reported by Copur (2006), Giri et al., (2008) and Bharathi et al., (2012). The differences in number of sympodial branches plant $^{-1}$ can be attributed to differences in genetic makeup of the genotypes, wherein in due to more plant height, duration and deep rooted system, number of sympodial branches also increases relative to the different genotypes.

\section{Effect of Plant density}

The number of sympodial branches plant ${ }^{-1}$ was found to vary non significantly among 
different plant densities at 60 DAE and 90 DAE. But numerically normal planting at a level of $100 \%$ was recorded more number of sympodial branches plant ${ }^{-1}$ than high density planting at a level of $150 \%$ and $200 \%$ at 60 DAE and 90 DAE. At 120 DAE, normal plant density (100\%) recorded maximum number of sympodial branches plant ${ }^{-1}$ (17.33) at par with high density planting at $150 \%\left(\mathrm{P}_{2}\right)$ and significantly higher than high density planting at $200 \%\left(\mathrm{P}_{3}\right)$. Treatments $\mathrm{P}_{2}$ and $\mathrm{P}_{3}$ were statistically at par. This shows greater encouragement for reproductive growth in individual plant under normal planting density. Plant spacings directly influence resources use which in turn influences branching. Under high density planting there may be excess competition for photoassimilates needed for reproductive development. Plants direct lower percentage of daily produced total dry mass to reproductive development (Darawsheh et al., 2007). Whereas, Wali and Koraddi (1989), Jagtap and Bhale (2011), Paslawar et al., (2015) and Shekar et al., (2015) reported that increasing planting density affected the plant dry matter partitioning that related with number of sympodial branches plant ${ }^{-1}$. With increases in planting density, Number of sympodial branches plant ${ }^{-1}$ were decreases.

\section{Leaf area per plant}

\section{Effect of Genotype}

Different genotypes had significant influence on the leaf area plant ${ }^{-1}$ observed at 60,90 and 120 days after emergence of crop. At all the observed stages of observation Bt cotton genotype Balwan $\left(\mathrm{V}_{3}\right)$ produced significantly higher leaf area plant ${ }^{-1}$ than hirsutum genotype AKH $081\left(\mathrm{~V}_{1}\right)$ and arboreum genotype AKA $7\left(\mathrm{~V}_{2}\right)$. The latter two genotypes produced statistically similar leaf area plant ${ }^{-1}$ at all the stages. Bt balwan and hirsutum AKH 081 genotypes have Broad-leaf expression while arboreum AKA 7 has okra leaf shape. However, AKA 7 genotype bears more number of leaves compensating for its comparatively lower area of individual okra leaf. Differences in leaf area plant $^{-1}$ may be mainly ascribed to differences in genetic makeup of the genotypes.

\section{Effect of Plant density}

Differences in leaf area plant ${ }^{-1}$ due to different planting densities were significant and leaf area plant ${ }^{-1}$ showed decreasing trend with increasing plant density $\left(\mathrm{P}_{1}\right.$ to $\left.\mathrm{P}_{3}\right)$ at all the observed growth stages of the crop. Normal planting density $(100 \%)$ produced significantly higher leaf area plant $^{-1}$ at all observed stages of crop growth. However, it was on par with high density planting at $150 \%$ of normal population $\left(\mathrm{P}_{2}\right)$, except at $120 \mathrm{DAE}$, and statistically more over high density planting at $200 \%\left(\mathrm{P}_{3}\right)$. Treatment $\mathrm{P}_{2}$ was statistically equivalent to $\mathrm{P}_{3}$ except at 120 DAE whereat it noted significantly higher leaf area plant ${ }^{-1}$ than $\mathrm{P}_{3}$. Maximum leaf area plant ${ }^{-1}$ with lower plant density could be due to higher number of leaves plant ${ }^{-1}$ and better leaf expansion as a consequence of more favourable share of resources (moisture, light radiation and nutrients) by individual plant.

\section{Leaf area index}

Leaf area index characterizes the canopyatmosphere interface, where most of the energy fluxes exchange. Leaf area index (LAI) was computed treatment wise from 30 to 120 DAE.

\section{Effect of Genotype}

Leaf area index was the maximum with AKH 081 $\left(\mathrm{V}_{1}\right)$ at 30 and $60 \mathrm{DAE}$. At 90 and 120 DAE it was maximum with AKA $7\left(V_{2}\right)$. However, both genotypes were statistically at par with each other and exhibited significantly 
higher LAI as compared to Bt cotton Balwan $\left(\mathrm{V}_{3}\right)$. This could be mainly due to relatively wider plant spacing of $\mathrm{Bt}$ cotton genotype accommodating more ground area plant $^{-1}$, although it produced significantly higher leaf area plant ${ }^{-1}$.

\section{Effect of Plant density}

Plant density significantly influenced the leaf area index. Leaf area index showed increasing trend with increasing plant density $\left(\mathrm{P}_{1}\right.$ to $\left.\mathrm{P}_{3}\right)$ at all the observed growth stages. High density planting at $200 \%$ of normal population $\left(\mathrm{P}_{3}\right)$ showed significantly higher leaf area index than $150 \%\left(\mathrm{P}_{2}\right)$ and normal $(100 \%)$ planting densities. Reduced ground area plant ${ }^{-1}$ with higher population densities caused more LAI in high density planting. This corroborates the findings of Dongsheng Zhang et al., (2014) who observed that cotton leaf area index increased but plant height decreased with plant density. Treatment combinations of genotypes AKH-081 and AKA 7 with high density planting at $200 \%$ of normal population $\left(\mathrm{V}_{1} \mathrm{P}_{3}\right.$ and $\mathrm{V}_{2} \mathrm{P}_{3}$ ), being at par with each other, recorded significantly higher LAI than the rest at 30, 60,90 and 120 DAE. Both AKH-081 and AKA-7 genotypes recorded statistically similar LAI at the corresponding level of plant density. Genotype Balwan under all the three plant density levels recorded significantly lower LAI compared to the remaining two genotypes at all the stages of observed interaction effect. According to Babiker et al., (2006) leaf area index (LAI) which can be used as a measurement of light interception efficiency increased via increasing plant density with concomitant yield decrease due to shading. On the other hand, the decrease in specific leaf weight (SLW) with the increase in plant density indicated that leaves of the highest density had less weight per leaf area and therefore were very thin and they behaved like shade leaves because of competition for light.

\section{Leaf area index interaction}

Treatment combinations of genotypes AKH081 and AKA 7 with high density planting at $200 \%$ of normal population $\left(\mathrm{V}_{1} \mathrm{P}_{3}\right.$ and $\left.\mathrm{V}_{2} \mathrm{P}_{3}\right)$, being at par with each other, recorded significantly higher LAI than the rest at 30, 60,90 and 120 DAE. Both AKH-081 and AKA-7 genotypes recorded statistically similar LAI at the corresponding level of plant density. Genotype Balwan under all the three plant density levels recorded significantly lower LAI compared to the remaining two genotypes at all the stages of observed interaction effect. According to Babiker et al., (2006) leaf area index (LAI) which can be used as a measurement of light interception efficiency increased via increasing plant density with concomitant yield decrease due to shading. On the other hand, the decrease in specific leaf weight (SLW) with the increase in plant density indicated that leaves of the highest density had less weight per leaf area and therefore were very thin and they behaved like shade leaves because of competition for light.

\section{Dry matter weight per plant}

Total dry matter production is the integral component of crop growth rate over the entire growth period, and it is related to grain yield by the harvest index. During the crop growing period increase in dry matter weight plant ${ }^{-1}(\mathrm{~g})$ was continuous up to $150 \mathrm{DAE}$, from 2.28 to $68.23 \mathrm{~g}$. Subsequently at harvest it declined $(52.16 \mathrm{~g})$ due to leaf senescence and picking of burst bolls. The rate of increase was very slow up to 30 days (3.34\%). Thereafter it accelerated with stage of growth i.e. at 60 (26.71\%), $90(64.86 \%)$ till 120 days $(90.22 \%)$. From $120^{\text {th }}$ day further increase till 150 DAE was comparatively small $(9.78 \%)$. Therefore the maximum quantitative increase in dry matter weight was observed between 60 to 90 DAE followed by 90 to 120 DAE. 


\section{Effect of Genotype}

Different genotypes showed significant differences in dry matter weight plant ${ }^{-1}(\mathrm{~g})$ at various growth stages. Bt cotton Balwan $\left(\mathrm{V}_{3}\right)$ accumulated significantly higher dry matter weight plant ${ }^{-1}$ as compared to AKH $081\left(\mathrm{~V}_{1}\right)$ and AKA $7\left(\mathrm{~V}_{2}\right)$ at all stages of crop growth. Genotype AKA 7 recorded significantly higher dry matter weight plant $^{-1}$ than AKH$081\left(\mathrm{~V}_{1}\right)$ at 60, 90, 120 and 150 DAE, however, being statistically at par at $30 \mathrm{DAE}$ and harvest stage. Bt cotton Balwan inherently produced comparatively more vegetative/reproductive growth in terms larger leaves, resultantly larger leaf area plant ${ }^{-1}$ and hence more photo-assimilates to cater greater number bolls plant ${ }^{-1}$ and higher boll weight consequently causing higher dry matter weight plant $^{-1}$ (Sisodia and Khamparia, 2007; Giri et al., 2008; and Ban, 2015).

\section{Effect of plant density}

Total dry matter accumulation (g) plant 1 was significantly influenced due to different plant densities at various growth stages of cotton. Cotton plants under normal planting density $\left(\mathrm{P}_{1}\right)$ accumulated significantly higher dry matter plant ${ }^{-1}$ than both high planting densities of $150 \% \quad\left(\mathrm{P}_{2}\right)$ and $200 \%\left(\mathrm{P}_{3}\right)$ of normal population at all observed crop growth stages. However, It was at par with $150 \%$ planting density at 30 and 60 DAE. Similarly $150 \%$ and $200 \%$ planting densities were at par at 30 and 60 DAE but subsequently from 90 DAE till harvest stage the former proved significantly. Darawsheh et al., (2007) and Jadhav et al., (2015) noticed that Plant spacing directly influences soil moisture extraction, light interception, soil nutrients use, canopy aeration etc. which in turn influence vegetative and reproductive development of a plant. Under high density planting as root and leaf surfaces become larger plants compete for growth resources and with excessive competition for limited resources each plant in a dense stand receives less sunlight, water and nutrients which translate into reduced photoassimilates and hence lower dry matter production plant ${ }^{-1}$.

\section{Yield attributing characters}

\section{Number of picked bolls per plant}

\section{Effect of Genotype}

Genotypic differences in influencing the number of picked bolls plant ${ }^{-1}$ were found to be significant. Bt cotton Balwan $\left(\mathrm{V}_{3}\right)$ recorded significantly higher number of picked bolls plant $^{-1}$ (17.59) as compared to arboreum genotype AKH $081\left(\mathrm{~V}_{2}, 6.78\right)$ and hirsutum genotype $\left(\mathrm{V}_{1}, 5.58\right)$. Number of picked bolls plant $^{-1}$ in AKA 7 was significantly more than AKH 081, which recorded the least number of picked bolls plant ${ }^{-1}$. Copur (2006), Singh et al., (2012) and Ban (2015) noticed that the differences among genotypes for number of picked bolls plant ${ }^{-1}$ might have been due to the difference in genetic potential of the genotypes and comparatively higher retention of bolls by Bt cotton genotype.

\section{Effect of Plant density}

Number of bolls picked plant ${ }^{-1}$ was the maximum with normal planting density of $100 \%$ population $\left(\mathrm{P}_{1}, 11.67\right)$ which was significantly more over high planting densities of $150 \%\left(\mathrm{P}_{2}, 9.77\right)$ and $200 \%\left(\mathrm{P}_{3}, 8.51\right)$ of normal population. Treatment $\mathrm{P}_{2}$ (HDP-150\%) produced significantly higher number of bolls plant $^{-1}$ than $\mathrm{P}_{3}$ (HDP-200\%). Higher plant population under high density planting causes competition and fewer shares of limited resources to individual plants. Moreover, lower the plant population per hectare may increase light penetration to allow more resources for fruit development lower in the canopy which may increase retention and 
hence number of bolls. Kater Hake (1991) found that in dense stands fruiting branches are $25 \%$ shorter with more fruiting up the plants and slow development of new nodes. Resultantly plants produced fewer fruiting bodies and mature fruits plant ${ }^{-1}$. Whereas, Singh and Rathore (2007), Jahedi et al., (2013) and Paslawar et al., (2015) found that under normal planting density overall favourable plant growth and development reflected in better source - sink relationship, which in turn enhanced the yield attributes.

\section{Boll weight (g)}

\section{Effect of Genotype}

An evaluation of data indicated that greatest boll weight was recorded in Bt cotton Balwan $(3.21 \mathrm{~g})$ and it was significantly higher over that of hirsutum cotton AKH $081(2.10 \mathrm{~g})$ and arboreum cotton AKA 7 (2.01). The latter two genotypes were statistically at par with each other. Among Bt and non-Bt cultivars have Significant differences in their average boll weight (Hofs et al., 2006 and Ban, 2015).

\section{Effect of Plant density}

The boll weight was significantly influenced due to different plant densities. Normal planting at $100 \%$ population $\left(\mathrm{P}_{1}\right)$ recorded the maximum boll weight which was at par with $150 \%$ of planting density $\left(\mathrm{P}_{2}\right)$ and significantly higher over $200 \%$ planting density $\left(\mathrm{P}_{3}\right)$. According to Rose Roche (2003) under ultranarrow system in cotton less light is available to leaves lower in the canopy that are important for supporting boll growth.

This may be one reason why boll size is smaller despite there being fewer bolls plant ${ }^{-1}$. Venugopalan et al., $\left(2011^{\mathrm{a}}\right)$ reported that in both $G$. hirsutum and $G$. arboreum genotypes the boll weight and harvest index decreased with increasing plant density. Paslawar et al.,
(2015) also observed that that boll weight increased with decreased plant densities.

\section{Seed cotton weight (g) per plant}

\section{Effect of Genotype}

Differences in seed cotton weight plant $^{-1}$ of genotypes AKH $081\left(\mathrm{~V}_{1}\right)$, AKA $7\left(\mathrm{~V}_{2}\right)$ and Balwan $\left(V_{3}\right)$ were observed to be significant. Genotype Balwan recorded significantly higher seed cotton weight plant $^{-1}(56.49 \mathrm{~g})$ as compared to AKA 7 (14.34 g) and AKH 081 $(11.44 \mathrm{~g})$. Also weight of seed cotton plant $^{-1}$ noted in AKA 7 was significantly more than AKH 081.The maximum seed cotton weight plant $^{-1}$ with Bt cotton Balwan can be attributed to better expression of yield components viz. maximum number of number of bolls and boll weight than other two genotypes. These results are supported by Hofs et al., (2006) and Ban (2015). They were observed that cotton plant have genetically difference in boll retention, boll weight and number of bolls plant $^{-1}$ that affect the seed cotton yield plant ${ }^{-1}$.

\section{Effect of Plant density}

Among different plant densities, seed cotton weight plant $^{-1}$ was highest with normal planting density of $100 \%$ population $\left(\mathrm{P}_{1}, 33.97\right.$ g) which was significantly higher over high planting densities of $150 \%\left(\mathrm{P}_{2}, 27.44 \mathrm{~g}\right)$ and $200 \%\left(\mathrm{P}_{3}, 20.87 \mathrm{~g}\right)$ of normal population. Treatment $\mathrm{P}_{2} \quad$ (HDP-150\%) produced significantly higher seed cotton weight plant $^{-1}$ than $\mathrm{P}_{3}$ (HDP-200\%). Giri et al., (2008) and Darawsheh et al.,(2009) observed that normal or optimum plant population while optimizing resource use produced more boll number and boll weight that reflected in higher seed cotton weight plant ${ }^{-1}$. Under high density population probably due to reduced availability of resources to individual plant resultantly fewer boll number and smaller boll weight reflected in reduced seed cotton weight plant ${ }^{-1}$. 
Table.1 Treatment details along with symbol used

\begin{tabular}{|l|l|}
\hline \multicolumn{1}{|l|}{ Treatment } \\
\hline A & Genotype \\
\hline $\mathrm{V}_{1}$ & AKH-081 (hirsutum) \\
\hline $\mathrm{V}_{2}$ & AKA-7 (arboreum) \\
\hline $\mathrm{V}_{3}$ & Balwan $($ Bt Cotton) \\
\hline B & Plant density \\
\hline $\mathrm{P}_{1}$ & NP $-100 \%\left(60 \times 15 \mathrm{~cm}^{*}, 90 \times 45 \mathrm{~cm}^{* *}\right)\left(111111,24691\right.$ plants $\left.^{-1}\right)$ \\
\hline $\mathrm{P}_{2}$ & HDP $-150 \%\left(60 \times 10 \mathrm{~cm}^{*}, 90 \times 30 \mathrm{~cm}^{* *}\right)\left(166666,37037\right.$ plants ha $\left.^{-1}\right)$ \\
\hline $\mathrm{P}_{3}$ & HDP $-200 \%\left(45 \times 10 \mathrm{~cm}^{*}, 45 \times 45 \mathrm{~cm}^{* *}\right)\left(22222,49382\right.$ plants ha $\left.^{-1}\right)$ \\
\hline
\end{tabular}

* spacing of arboreum and hirsutum genotypes, ** spacing of Bt genotype

$V$-Variety, P-Planting density, NP-Normal planting density, HDP-High density planting

Table. 2 Growth parameters as influenced by various treatments

\begin{tabular}{|c|c|c|c|c|c|}
\hline Treatment & $\begin{array}{l}\text { Plant height } \\
\text { (cm) }\end{array}$ & $\begin{array}{l}\text { Number of sympodial } \\
\text { branches plant }^{-1}\end{array}$ & $\begin{array}{c}\text { Leaf area plant }{ }^{-1} \\
\left(\mathrm{dm}^{2}\right)\end{array}$ & $\begin{array}{l}\text { Leaf area } \\
\text { index }\end{array}$ & $\begin{array}{l}\text { Total dry matter } \\
\text { accumulation plant }^{-1}(\mathrm{~g})\end{array}$ \\
\hline \multicolumn{6}{|l|}{ Genotype } \\
\hline $\mathrm{V}_{1}$-AKH 081 & 80.6 & 12.20 & 20.05 & 3.439 & 24.51 \\
\hline $\mathrm{V}_{2}$-AKA 7 & 121.6 & 19.27 & 21.20 & 3.628 & 28.76 \\
\hline $\mathrm{V}_{3}$-Balwan & 102.7 & 16.60 & 33.02 & 1.197 & 103.21 \\
\hline $\mathrm{SE}(\mathrm{m}) \pm$ & 3.3 & 0.61 & 0.51 & 0.069 & 1.73 \\
\hline$C D(p=0.05)$ & 9.9 & 1.84 & 1.53 & 0.207 & 5.20 \\
\hline \multicolumn{6}{|l|}{ Plant density } \\
\hline $\mathrm{P}_{1}-\mathrm{NP} 100 \%$ & 107.3 & 17.33 & 27.02 & 2.048 & 58.13 \\
\hline $\mathbf{P}_{2}$-HDP $150 \%$ & 102.0 & 15.84 & 24.87 & 2.787 & 51.86 \\
\hline $\mathbf{P}_{3}$-HDP $200 \%$ & 95.6 & 14.89 & 22.39 & 3.430 & 46.49 \\
\hline SE(m) \pm & 3.3 & 0.61 & 0.51 & 0.069 & 1.73 \\
\hline $\mathrm{CD}(\mathrm{p}=0.05)$ & 9.9 & 1.84 & 1.53 & 0.207 & 5.20 \\
\hline \multicolumn{6}{|l|}{ Interaction } \\
\hline $\mathrm{SE}(\mathrm{m}) \pm$ & 5.7 & 1.06 & 0.89 & 0.119 & 3.00 \\
\hline$C D(p=0.05)$ & NS & NS & NS & 0.358 & NS \\
\hline GM & 101.6 & 16.02 & 24.76 & 2.755 & 52.16 \\
\hline
\end{tabular}




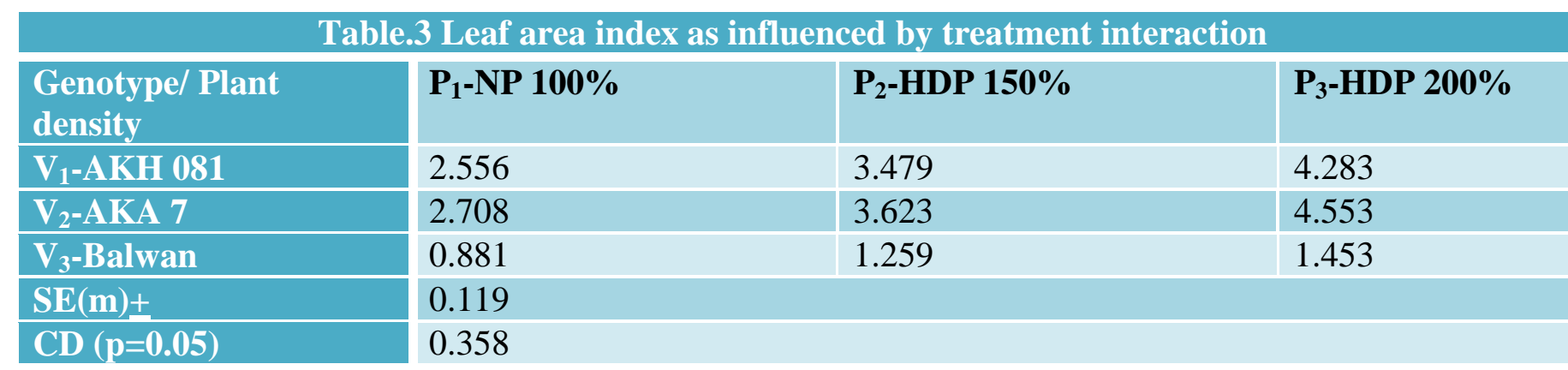

Table.4 Yield related parameters as influenced by various treatments

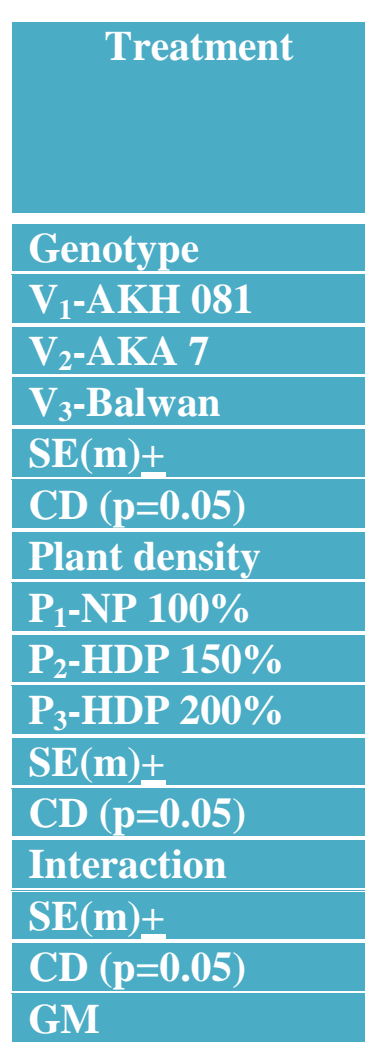

\begin{tabular}{|c|c|c|c|c|c|c|c|c|}
\hline $\begin{array}{l}\text { Number of } \\
\text { picked bolls } \\
\text { plant }^{-1}\end{array}$ & $\begin{array}{c}\text { Boll } \\
\text { weight } \\
\text { (g) }\end{array}$ & $\begin{array}{c}\text { Seed } \\
\text { cotton } \\
\text { weight } \\
\left(\text { g plant }^{-1}\right)\end{array}$ & $\begin{array}{c}\text { Seed } \\
\text { cotton } \\
\text { yield } \\
\left(\mathrm{kg} \mathrm{ha}^{-1}\right)\end{array}$ & $\begin{array}{l}\text { Cotton } \\
\text { stalk } \\
\text { yield } \\
\left(\mathrm{kg} \mathrm{ha}^{-1}\right)\end{array}$ & $\begin{array}{c}\text { Biological } \\
\text { yield } \\
\left(\mathrm{kg} \mathrm{ha}^{-1}\right)\end{array}$ & $\begin{array}{l}\text { Harvest } \\
\text { index } \\
(\%)\end{array}$ & $\begin{array}{l}\text { Ginning } \\
\text { out turn } \\
(\%)\end{array}$ & $\begin{array}{l}\text { Seed } \\
\text { Index } \\
(\mathrm{g})\end{array}$ \\
\hline 5.58 & 2.10 & 11.44 & 1466 & 2718 & 4184 & 35.12 & 38.92 & 7.64 \\
\hline 6.78 & 2.01 & 14.34 & 1715 & 3038 & 4753 & 36.31 & 40.11 & 6.10 \\
\hline 17.59 & 3.21 & 56.49 & 1571 & 2443 & 4014 & 39.50 & 37.87 & 8.65 \\
\hline 0.38 & 0.09 & 0.77 & 46 & 90 & 130 & 0.48 & 0.14 & 0.04 \\
\hline 1.14 & 0.27 & 2.32 & 138 & 271 & 391 & 1.44 & 0.41 & 0.11 \\
\hline 11.67 & 2.65 & 33.97 & 1271 & 2080 & 3351 & 38.08 & 38.81 & 7.54 \\
\hline 9.77 & 2.56 & 27.44 & 1679 & 2781 & 4460 & 37.77 & 39.00 & 7.50 \\
\hline 8.51 & 2.11 & 20.87 & 1802 & 3338 & 5140 & 35.07 & 39.09 & 7.35 \\
\hline 0.38 & 0.09 & 0.77 & 46 & 90 & 130 & 0.48 & 0.14 & 0.04 \\
\hline 1.14 & 0.27 & 2.32 & 138 & 271 & 391 & 1.44 & $\mathrm{NS}$ & 0.11 \\
\hline 0.66 & 0.16 & 1.34 & 79 & 156 & 226 & 0.83 & 0.24 & 0.06 \\
\hline NS & NS & 4.01 & NS & NS & $\mathrm{NS}$ & $\mathrm{NS}$ & NS & NS \\
\hline 9.98 & 2.44 & 27.42 & 1584 & 2733 & 4317 & 36.97 & 38.96 & 7.46 \\
\hline
\end{tabular}


Int.J.Curr.Microbiol.App.Sci (2018) 7(6): 1872-1888

\begin{tabular}{|c|c|c|c|}
\hline \multicolumn{4}{|c|}{ Table.5 Seed cotton weight plant ${ }^{-1}(\mathrm{~g})$ as influenced by treatment interactions } \\
\hline Genotype/ Plant density & $P_{1}$-NP $100 \%$ & $\mathbf{P}_{2}$-HDP $150 \%$ & $\mathbf{P}_{3}$-HDP $200 \%$ \\
\hline V1-AKH 081 & 15.07 & 11.55 & 7.70 \\
\hline$V_{2}-A K A 7$ & 18.47 & 14.27 & 10.30 \\
\hline$\overline{V_{3} \text {-Balwan }}$ & 68.37 & 56.50 & 44.60 \\
\hline $\mathrm{SE}(\mathrm{m}) \pm$ & \multicolumn{3}{|l|}{1.34} \\
\hline $\mathrm{CD}(\mathrm{p}=0.05)$ & \multicolumn{3}{|l|}{4.01} \\
\hline \multicolumn{4}{|c|}{ Table.6 Seed cotton yield ( $\mathrm{kg} \mathrm{ha}^{-1}$ ) under different treatment interactions } \\
\hline Genotype/ Plant density & $P_{1}-\mathrm{NP} 100 \%$ & $\mathbf{P}_{2}$-HDP $150 \%$ & $\mathbf{P}_{3}$-HDP $200 \%$ \\
\hline $\mathrm{V}_{1-\mathrm{AKH}} 081$ & 1135 & 1569 & 1694 \\
\hline $\mathbf{V}_{2}$-AKA 7 & 1445 & 1813 & 1886 \\
\hline $\mathrm{V}_{\mathbf{3}^{-B}}$ Balwan & 1231 & 1655 & 1826 \\
\hline $\mathbf{S E}(\mathbf{m}) \pm$ & 79 & & \\
\hline $\mathrm{CD}(\mathrm{p}=0.05)$ & NS & & \\
\hline
\end{tabular}




\section{Interaction effect}

Treatment combination of $\mathrm{Bt}$ cotton genotype Balwan with normal density planting $\left(\mathrm{V}_{3} \mathrm{P}_{1}\right)$, recorded significantly higher seed cotton weight plant ${ }^{-1}$ than rest of the combinations. Both AKH-081 and AKA-7 genotypes recorded statistically similar seed cotton weight plant $^{-1}$ at the corresponding level of plant density. AKA-7 and AKH-081 under all the three plant density levels recorded significantly lower seed cotton weight plant ${ }^{-1}$ compared to Balwan at the corresponding level of plant density.

\section{Yield studies}

\section{Seed cotton yield (kg/ha)}

\section{Effect of Genotype}

All the cotton genotypes differed from each other for seed cotton yield ha ${ }^{-1}$. AKA 7 (G. arboreum) registered significantly higher seed cotton yield (1715 kg ha $\left.{ }^{-1}\right)$ than $\mathrm{Bt}$ cotton Balwan (1571 kg ha-1) and hirsutum non-Bt AKH $081\left(1466 \mathrm{~kg} \mathrm{ha}^{-1}\right)$. The latter two genotypes were statistically at par. Among the three genotypes $\mathrm{Bt}$ cotton Balwan produced maximum leaf area plant ${ }^{-1}$, dry matter weight plant $^{-1}$, greater number and size (weight) of bolls and higher seed cotton weight plant ${ }^{-1}$ followed by genotypes AKA 7 and AKH 081 .

Genotype AKA 7 although had lower leaf area plant ${ }^{-1}$, dry matter weight plant ${ }^{-1}$, smaller boll size and fewer bolls plant ${ }^{-1}$ and seed cotton weight plant $^{-1}$, however, its conventional density accommodating markedly higher per unit population than in Balwan, compensated for lower values of yield attributes plant ${ }^{-1}$ and produced higher yield level with better tolerance to the short term weather fluctuations during the growing season (Jagvir Singh et al., 2012). Comparatively lower yield level in AKH 081 appears to be more due to incidence of bollworm complex, besides its genetic potential (Venugopalan et al., 2011).

\section{Effect of Plant density}

High density planting at $200 \%$ of normal density $\left(\mathrm{P}_{3}\right)$ produced maximum seed cotton yield $\left(1802 \mathrm{~kg} \mathrm{ha}^{-1}\right)$ which was at par with seed cotton yield obtained (1679 $\left.\mathrm{kg} \mathrm{ha}^{-1}\right)$ under $150 \%$ of normal plant density $\left(\mathrm{P}_{2}\right)$. Normal plant density (100\%) yielded the least seed cotton $\left(1271 \mathrm{~kg} \mathrm{ha}^{-1}\right)$. The high density planting treatments (HDP-200\% and HDP$150 \%$ ) generally had smaller individual boll size (weight) and fewer bolls plant ${ }^{-1}$, however, the increased number of plants compensated for fewer boll number and smaller boll size and cumulatively yield output was significantly higher in both the high density planting treatments as compared to conventional (100\%) planting density. These results are in agreement with reports of Bhalerao et al., (2012) and Paslawar et al., (2015).

\section{Interaction effect}

Interaction effects between treatments were found to be statistically non-significant. However, the seed cotton yield data under treatment interactions are given in Table for numerical comparison. Numerically treatment combination of $\mathrm{V}_{2} \mathrm{P}_{3}$ (AKA 7 at HDP-200\%) yielded maximum seed cotton $\left(1886 \mathrm{~kg} \mathrm{ha}^{-1}\right)$ closely followed by $\mathrm{V}_{3} \mathrm{P}_{3}$ (Balwan at HDP$200 \%$ ) yielding $1826 \mathrm{~kg} \mathrm{ha}^{-1}$ seed cotton and $\mathrm{V}_{2} \mathrm{P}_{2}$ (AKA 7 at $\mathrm{HDP}-150 \%$ ) yielding 1813 $\mathrm{kg} \mathrm{ha}^{-1}$ seed cotton. Numerically the least seed cotton yield occurred under the treatment combination of $\mathrm{V}_{1} \mathrm{P}_{1}\left(1135 \mathrm{~kg} \mathrm{ha}^{-1}\right)$.

\section{Cotton stalk yield (kg/ha)}

\section{Effect of Genotype}

Differences in stalk yield were significant among the genotypes under study. Genotype 
AKA $7\left(\mathrm{~V}_{2}\right)$ recorded significantly higher stalk yield (3038 $\left.\mathrm{kgha}^{-1}\right)$ and comparatively significant decline in stalk yield was noticed under genotypes Balwan $\left(\mathrm{V}_{3}-2443 \mathrm{kgha}^{-1}\right)$ and AKH $081\left(\mathrm{~V}_{1}-2718 \mathrm{~kg} \mathrm{ha}^{-1}\right)$.

\section{Effect of Plant density}

Differences in stalk yield due to different planting densities were significant. HDP$200 \%\left(\mathrm{P}_{3}\right)$ recorded significantly higher stalk yield (3338 kg ha ${ }^{-1}$ ); followed by HDP-150\% $\mathrm{P}_{2}\left(2781 \mathrm{kgha}^{-1}\right)$ and NP-100\% $\mathrm{P}_{1}(2080 \mathrm{~kg}$ $\left.\mathrm{ha}^{-1}\right)$.

\section{Biological yield (kg/ha)}

\section{Effect of Genotype}

Among the different genotypes, biological yield $\left(\mathrm{kg} \mathrm{ha}{ }^{-1}\right)$ differed significantly. Maximum biological yield $\left(4753 \mathrm{~kg} \mathrm{ha}^{-1}\right)$ was recorded with genotype AKA-7 $\left(\mathrm{V}_{2}\right)$ which was significantly superior to AKH-081 $\mathrm{V}_{1}$ (4184 $\mathrm{kg} \mathrm{ha}^{-1}$ ) and Balwan $\mathrm{V}_{3}\left(4014 \mathrm{~kg} \mathrm{ha}^{-1}\right)$.

\section{Effect of Plant density}

Biological yield differed significantly due to various plant densities. Significantly higher biological yield $\left(5140 \mathrm{~kg} \mathrm{ha}^{-1}\right)$ was obtained with high density planting at $200 \%$ of normal population $\left(\mathrm{P}_{3}\right)$.

Next best treatment was high density planting at $150 \%$ of normal population $\mathrm{P}_{2}(4460 \mathrm{~kg} \mathrm{ha}$ $\left.{ }^{1}\right)$. Conventional planting at $100 \%$ population $\left(\mathrm{P}_{1}\right)$ produced the lowest biological yield $\left(3351 \mathrm{~kg} \mathrm{ha}^{-1}\right)$.

Although high planting densities (HDP-150\% and HDP-200\%) had lower dry matter accumulation by plants individually, however, with higher population cumulatively total biomass output was higher than under conventional planting density (NP-100\%).

\section{Harvest index}

High harvest index is an indicative of better translocation and mobilization of food reserve (Morthy and Rao, 1986, Rauf and Sadaqat, 2008).

\section{Effect of Genotype}

Cotton genotypes exhibited significant differences in terms of harvest index. Bt cotton genotype Balwan $\mathrm{V}_{3}$ recorded significantly higher harvest index $(39.50 \%)$ whereas hirsutum non-Bt AKH $081 \mathrm{~V}_{1}$ recorded the lowest harvest index (35.12\%). As such both non-Bt genotypes i.e. arboreum AKA 7 (36.31\%) and hirsutum AKH 081 were statistically at par. Higher harvest index shows better translocation efficiency in genotype Balwan.

\section{Effect of Plant density}

Differences in harvest index due to different planting densities were statistically significant. NP-100\% $\left(\mathrm{P}_{1}\right)$ recorded the maximum harvest index $(38.08 \%)$ significantly higher than HDP-150\% $\mathrm{P}_{2}$ (37.77\%), HDP-200\% P3 (35.07).

The finding shows better translocation efficiency under conventional planting $(100 \%)$ as compared to high planting densities (HDP-150\% and 200\%).

Venugopalan et al., (2013) also reported that harvest index decreases due to increase of leaf area index associated with high population densities reduce the efficiency of photosynthetic photon flux density interception per plant area.

In this case a greater proportion of photoassimilates is directed to the vegetative growth rather than reproductive thus reducing harvest index (Darawsheh et al., 2007). 


\section{Ginning out turn (\%)}

\section{Effect of Genotype}

Data revealed that ginning out turn was significantly influenced by genotypic differences. The highest value of ginning out turn $(40.11 \%)$ was obtained in case of genotype AKA 7. It was followed by AKH 081 (38.92\%) and Balwan (37.87\%). These findings are in consonance with those reported by by Copur (2006) and Ban (2015).

\section{Effect of Plant density}

Ginning out turn did not differ significantly under different plant densities. Numerically, high density planting at $200 \%$ recorded maximum ginning out turn $(39.09 \%)$ followed by high density planting at $150 \%(39.00 \%)$ and normal planting density at 100\% (38.81). Reddy and Gopinath (2008), Reddy and Kumar (2010) also reported that ginning percentage was free of population pressure.

\section{Seed index}

\section{Effect of Genotype}

Genotypic differences were significant for seed index. Bt cotton genotype Balwan $\left(\mathrm{V}_{3}\right)$ recorded higher seed index $(8.65 \mathrm{~g})$ followed by hirsutum AKH $081 \quad\left(\mathrm{~V}_{1}-7.64 \mathrm{~g}\right)$ and arboreum AKA $7\left(\mathrm{~V}_{2}-6.10 \mathrm{~g}\right)$ genotypes.

\section{Effect of Plant density}

Seed index was significantly influenced by different planting densities. Normal planting density at $100 \%$ population level $\left(\mathrm{P}_{1}\right)$ noted higher seed index $(7.54 \mathrm{~g})$. It was statistically at par with high density planting at $150 \%$ population level $\left(\mathrm{P}_{2}-7.51 \mathrm{~g}\right)$ And significantly more than $200 \%$ population level $\left(\mathrm{P}_{3}-7.35 \mathrm{~g}\right)$ Treatment $\mathrm{P}_{2}$ also proved superior to $\mathrm{P}_{3}$. This appears in contrast to Darawsheh et al.,
(2007) who observed that plants in narrow row high population density produced lower fibre proportion or higher seed proportion. However, according to Dhillon et al., (2006) plants under wider plant spacing produced higher seed index.

On the basis of the results obtained from present investigation following conclusions emerged.

Bt cotton genotype Balwan recorded higher growth in terms of leaf area, dry matter weight and yield attributes of individual plant than arboreum AKA-7 and hirsutum AKH 081 genotypes. Cotton planting at $150 \%$ to $200 \%$ of normal population density lowered growth and yield attributes of individual plant and caused earlier maturity of crop comparative to normal population density. Whereas, Cotton genotype AKA-7 (G.arboreum) recorded the maximum seed cotton yield per hectare followed by Balwan (Bt cotton) and AKH-081(G.hirsutum). High density planting at $200 \%$ of normal population density produced maximum seed cotton yield per hectare which was at par with seed cotton yield from $150 \%$ of normal population density. The increased number of plants compensated for fewer yield attributes plant $^{-1}$ and cumulatively yield output was higher in conventionally close spaced genotype (AKA-7) and with the high density planting system (150\% to $200 \%$ of normal population density). Balwan recorded higher harvest index followed by AKA 7 and AKH 081. Ginning out turn was maximum in case of genotype AKA 7 but it found nonsignificant with planting densities while seed index was maximum with genotype Balwan and $100 \%$ planting density.

\section{References}

Anwar, A. M., M.I. Gill, D. Muhammad and M.N. Afzal, 2002. Evaluation of cotton 
varieties at different doses of nitrogen fertilizer. The Pak. Cottons, 46(1-4): 3541.

Babiker, E.A., A. Hamada, H.O. Kanan, S.B. Ahmed and A.H. Abdelatif, 2006. Effect of plant density on growth, yield and quality of morphologically varying cotton varieties. https://www.researchgate.net/publicatio n

/268051937_Effect_of_plant_density_o

n_growth_yield_and_quality

_of_morphologically_varying_cotton_v arieties.

Ban, Yogesh G., D.P. Nawalkar, B.M. Mote, V. Kumar, A.V. Narwade, 2015. Crop phenology, thermal requirement, yield and fiber properties of cotton (Gossypium hirsutum) genotypes as influenced by different environments, Ind. J. Plant Physiol., 20(2):137-144.

Bhalerao, P. D., P.W. Deshmukh, Gadavari. S. Gaikwad and S. R. Imade, 2012. Response of $\mathrm{Bt}$ cotton (Gossypium hirsutum L.) to spacing and fertilizer levels under rainfed condition. Indian $J$. of Agron. 57 (2): 18-21.

Bharathi, S. G., M. V. Prasad Rao, S. Ratna Kumari and V. Chenga Reddy, 2012. Influence of plant geometry and nitrogen levels on performance of cotton hybrids under rainfed condition in vertisols of Andhra Pradesh. $J$. Cotton Res. Dev. 26 (2): 204-206.

Copur, O., 2006. Determination of yield and yield components of some cotton cultivars in semi-arid conditions. Pak. J Biol. Sci., 9(14) 2572-2578.

Darawsheh, M. K., E. M. Khah, G. Aivalakis, D. Chachalis and F. Sallaku, 2009. Cotton row spacing and plant density cropping systems I. Effects on accumulation and partitioning of dry mass and LAI. J. Food Agric. Environ., 7, 258-261.
Darawsheh, M.K., G. Aivalakis and D.L. Bouranis, 2007. Effect of cultivation system on cotton development, seed cotton production and lint quality. The European J. Plant Sci. and Biotechnology. 1(2)-206-213.

Dhillon, G.S., K.L. Chabra and S.S. Punia, 2006. Effect of crop geometry and integrated nutrient management on fibre quality and nutrient uptake by cotton crop. J. Cotton Res. Dev. 20(2):221223.

Dongsheng Zhang, Lizhen Zhang, Jianguo Liu, Shuo Han, Qi Wang, Jochem Evers, Jun Liu, Wopke van der Werf, Long Li, 2014. Plant density affects light interception and yield in cotton grown as companion crop in young jujube plantations. Field Crops Research 169:132-139.

Giri, A. N, R.L. Aundhekar, P.S. Kapse and S. B. Suryavanshi, 2008. Response of Bt cotton hybrids to plant densities and fertilizer levels. J. Cotton Res. Dev. 22 (1): 45-47,

Gomez, K. A. and A. A. Gomez, 1984. Statistical procedure for Agricultural Research. An International Rice Research institute Book. A Wiley Inter Science Publication, New York.

Hake, K., Tom Burch, Lawrence Harvey, Tom Kerby and James Supak, 1991. Plant population. In Physiology Today Newsletter of the Cotton Physiology Education Program-NATIONAL COTTON COUNCIL (NCC), Memphis February, 2(4): 1-4

Hake, K.D., D.M. Basset, T.A. Kerby and W.D. Mayfield, 1996. Producing quality cotton. In: Cotton Production Manual, University of California, Division of Agriculture and Natural Resources, Oakland, CA,pp 134-149.

Hofs, J. L., B. Hau and D. Marais, 2006. Boll distribution patterns in $\mathrm{Bt}$ and non-Bt cotton cultivars: I. Study on commercial 
irrigated farming systems in South Africa. Field Crops Res., 98(2 \& 3): 203-209.

Jadhav, S. G., B.A. Chavan and Y.M. Waghmare, 2015. Effect of plant spacing growth regulator and nutrient management on yield, quality and economics of Bt cotton. J. Cotton Res. Dev. 29 (1) 48-52.

Jagtap, D. N. and V. M. Bhale, 2011. Effect of different plant spacing and nitrogen levels on deshi cotton hybrid (Gossypium arboreum L.). J. Agric. Sci.7, 123-125.

Jahedi, M.B., F. Vazin and M.R. Ramezani, 2013. Effect of row spacing on the yield of cotton cultivars. Cercetari Agronomice în Moldova. 4 (156):31-38.

Moola, R. and A.N. Giri, 2006. Response of newly released cotton ( $G$. hirsutum) varieties to plant densities and fertilizer levels. J. Cotton Res. Dev. 20(1):85-86.

Morthy, P.S.S. and R.C.N. Rao, 1986. Physiological basis of variation in pod yield of rainfed groundnut under different dates of sowing. Indian $J$. Agron. 31(1):106-108.

Paslawar, A. N., A. S. Deotalu and P. W. Nemade, 2015. High density planting of cotton variety $\mathrm{AKH}-081$ under rainfed condition of Vidharbha, ISSN 0972 5210, Plant archs, 15(2)1075-1077.

Pettigrew, H.T., Meredith Jr., W.R. Jr., and Zeng Linghe, 2013. Response of absolute and modern cotton genotypes to varying plant densities. J. Cotton Sci. 17:253-262.

Rauf, S. and H.A. Sadaqat, 2008. Effect of osmotic adjustment of root length and dry matter partitioning in sunflower under drought stress. Acta Agric. Scand. Section B. Soil and Plant Sci. 58(3): 252-260.

Reddy, R.R.P and D.B. Kumar, 2010. Yield and economics of $\mathrm{Bt}$ cotton as influenced spacing and nutritional levels PKV Res. J. 34 (1): 20-22.

Reddy, R.R.P and M. Gopinath, 2008. Influence of fertilizers and plant geometry on performance of Bt cotton hybrids. J. Cotton Res. Dev. 22(1):7880.

Rose, Roche, Michael Bange, Stephen Milroy and Graeme Hammer, 2003. Cotton growth in UNR systems. The Australian Cotton Grower, October-November 2003.

Shekar, K., M. Venkata Ramana, S.M. Ratna Kumari, 2015. Response of hybrid cotton to chloro mepiquat chloride and detopping under high density planting, Cotton Res. J. Dev. 29 (1) 84-86.

Siebert, J.D., A.M. Steward and B.R. Leonard, 2006. Comparative growth and yield of cotton planted at various densities and configurations- Agron. J.98:562-568.

Singh, Deepika B., Ramandeep Kaur M. Malhi and G. Sandhya Kiran, 2015. Assessing the impact of agronomic spacing conditions on biophysical and biochemical parameters along with yield and yield components in cotton, Intern. J. of Agron. and Agri. Res. 6, (1) :6-44.

Singh, Jagvir, Shilpa Babar, Shalu Abraham, M.V. Venugopalan, and G. Majumdar, 2012. Fertilization of High Density, Rainfed Cotton Grown on Vertisols of India. Better Crops. 96 (2): 26-28.

Singh, Kulvir and Pankaj Rathore, 2007. Effect of different spacing and nitrogen levels on growth and yield attributes of American cotton (Gossypium hirsutum L.) genotypes. J. Cotton Res. Dev. 21 (2): 178-179.

Singh, Kulvir, Harmandeep Singh, Pankaj Rathore and R. K. Gumber, 2012. Response of deshi cotton (Gossypium arboreum L.) genotypes to plant geometries and nutrient levels under 
irrigated condition. J. of Cotton Res. Dev. 26 (1): 58-61.

Sisodia, R.I. and S.K. Khamparia, 2007. American cotton varieties as influenced by plant densities and fertility levels under rainfed conditions. J. Cotton Res. Dev. 21(1):35-40.

Venugopalan, M. V. and D. B.laise, 2011. Effect of planting density and nitrogen levels on productivity and $\mathrm{N}$-use efficiency of rainfed upland cotton (Gossypium hirsutum). Indian J. of Agron. 48 (2): 356-360.

Venugopalan, M.V., A.H. Prakash, K.R. Kranthi, Rachana Deshmukh, M.S. Yadav and N.R. Tandulkar, 2011. Evaluation of Cotton Genotypes for High Density Planting Systems on Rainfed Vertisols of Central India. In
World Cotton research Conference-5 (book of papers), Mumbai 7-11 November 2011:341-346.

Wali, B.M. and V.R. Koraddi, 1989. Biometrical studies in rainfed cotton. Mysore J. Agri. Sci., 23: 441-6.

Wankhade, S.T., S.G. Kharche, R.M. Deshpande and D.M. Ghatol, 2001. Studies on cotton genotype under different sowing dates and spacing. New Approaches in Agriculture Technology. (1):17-22.

Zhang M., L. Duan, X. Tian, Z. Li 2006 Unicanazole-induced tolerance of soybean to water deficit stress in relation to changes in photosynthesis, hormones and antioxidant system, $J$. plant physio, 164: 709-701.

\section{How to cite this article:}

Arvind Kumar, Anil P. Karunakar and Anil Nath. 2018. Influences of Different Planting Density on Growth, Yield Attributes and Yields of hirsutum, arboreum and Bt Cotton. Int.J.Curr.Microbiol.App.Sci. 7(06): 1872-1888. doi: https://doi.org/10.20546/ijcmas.2018.706.223 